\title{
A STUDY OF INTRAOPERATIVE PLASMA EXPANSION WITH A BALANCED ELECTROLYTE SOLUTION
}

\author{
W. A. TwEEd, M.D., AND JohN G. WADE, M.D., F.R.C.P.(C)
}

THE HAZARDS of blood transfusion during anaesthesia are well known. It has been reported that replacement of operative blood loss by plasma expansion with balanced electrolyte solutions is effective and well tolerated., ${ }^{1,2}$ Therefore, this study was designed to quantitate the plasma volume expansion $(\Delta \mathrm{Pv})$ produced by the intraoperative infusion of an isotonic electrolyte solution (Normosol $\left.{ }^{\otimes}\right)$, and to establish its effectiveness in replacing operative blood loss.

\section{METHOD}

The plasma volumes of eleven surgical patients were measured before and after operation. Seven patients, the treatment group, received an isotonic electrolyte solution intraoperatively equal to approximately three times the measured blood loss. Four patients, the control group, received no intraoperative electrolyte solution. Patients were randomly assigned to treatment or control group.

Only patients in general good health, with no systemic disease and no clinical evidence of fluid deficit or excess, were selected. There was no discrimination as to age or sex. The surgical procedures were elective, for a localized disease process not involving a major body cavity. Blood loss was comparable between the two groups (Table I), although duration of operation and operative trauma varied considerably for individual patients (Table II).

TABLE I

Determination of Operative Blood Loss

\begin{tabular}{|c|c|c|c|c|c|c|c|c|c|c|c|c|}
\hline & \multicolumn{4}{|c|}{ Control } & \multicolumn{7}{|c|}{ Treatment } & \multirow[b]{2}{*}{ Mean } \\
\hline & 1 & 2 & 3 & 4 & 1 & 2 & 3 & 4 & $\mathbf{5}$ & 6 & 7 & \\
\hline Gravimetric $(\mathrm{ml})^{*}$ & 310 & 620 & 880 & 1000 & 400 & 670 & 400 & 1000 & 950 & 1050 & 1150 & 766 \\
\hline Radioisotope $(\mathrm{m} 1) \dagger$ & 430 & 720 & 690 & 730 & 620 & 600 & 720 & 980 & 1010 & 1200 & 1250 & 814 \\
\hline
\end{tabular}

* Gravimetric determinations were made by weighing sponges and measuring contents of suction bottles.

†Decrease in red cell volume was determined from pre- and postoperative blood volumes (I ${ }^{126}$ or $\mathrm{Cr}^{51}$ ), and operative blood loss was calculated by dividing $\mathrm{RV}$ loss by the average of the preand postoperative haematocrits ( $\mathrm{RV}$ loss $\times 2) /\left(\mathrm{Hct}_{0}+\mathrm{Hct}_{1}\right)$. The larger of these in each case was selected as the nearest approximation to the actual loss. In that case the mean loss of the treatment group was $920 \mathrm{ml}$, and the mean loss of the control group was $760 \mathrm{ml}$.

An attempt was made to standardize the preparation and anaesthetic procedures. All patients were fasted from midnight prior to the operation. Before this they were on regular ward diets. Intravenous 5 per cent dextrose in water $(D / w)$

${ }^{\circ}$ Dr. Tweed is in the Department of Anaesthesia, University of Manitoba; Dr. Wade is Professor and Head, Department of Anaesthesia, University of Manitoba and Winnipeg General Hospital.

Canad. Anaesth. Soc. J., vol. 17, no. 3, May 1970 


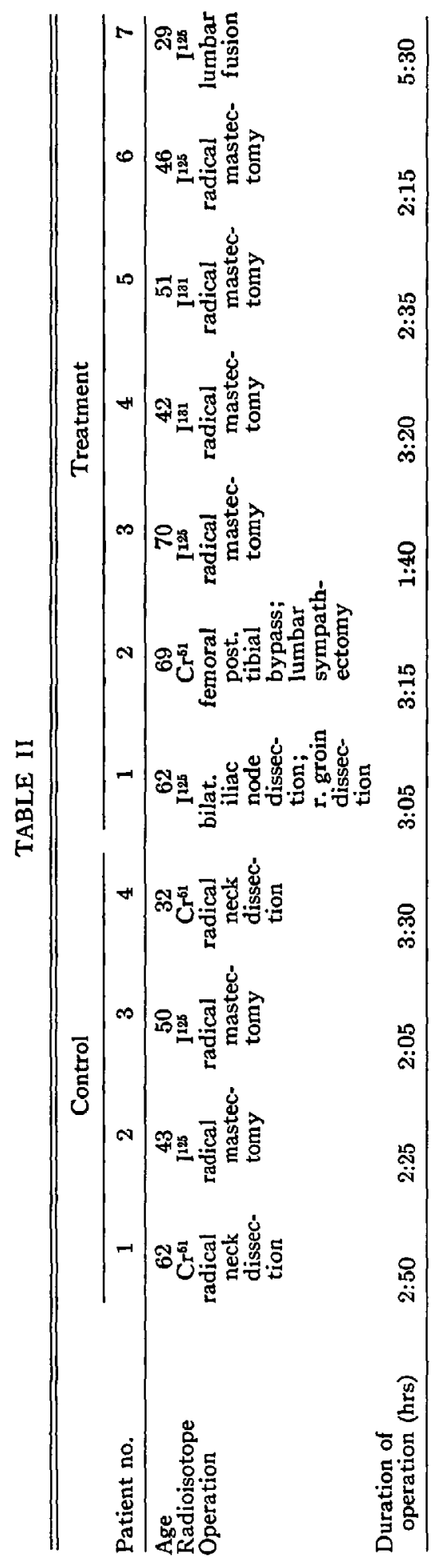


at $100 \mathrm{ml}$ per hour was begun at 0800 on the day of operation. Preoperative sedation was achieved with pentobarbital $100 \mathrm{mg}$ plus atropine $0.6 \mathrm{mg}$. Induction was by a sleep dose of thiopentone $(100-250 \mathrm{mg})$ or by mask with halothane and oxygen. Maintenance was on halothane- $\mathrm{O}_{2}$ or halothane- $\mathrm{N}_{2} \mathrm{O}-\mathrm{O}_{2}$ at 1 to 1.25 per cent inspired halothane concentrations. Respiration was controlled to keep arterial $\mathrm{P}_{\mathrm{CO}_{2}}$ levels between 30 and $40 \mathrm{~cm} \mathrm{H}_{2} \mathrm{O}$. Pulse, blood pressure, central venous pressure (CVP), and ECG were monitored. No patient became hypotensive during anaesthesia (systolic blood pressure less than $90 \mathrm{~cm} \mathrm{H}_{2} \mathrm{O}$ ) or had more than a transient change in cve.

Postoperatively the treatment group continued to receive electrolyte solution in sufficient amounts to maintain blood pressure and urine output. Seventy-two per cent of the total electrolyte solution of the operative day was administered intraoperatively, 28 per cent postoperatively (Table III). Patients in the control group received either blocd or electrolyte solution postoperatively.

TABLE III

Electrolyte Infusion and Plasma Expansion ( $\triangle$ Pv) during the Operative Day (Treatment Group)

\begin{tabular}{|c|c|c|c|c|c|c|c|c|}
\hline & \multicolumn{7}{|c|}{ Patient number } & \multirow[b]{2}{*}{ Mean } \\
\hline & 1 & 2 & 3 & 4 & 5 & 6 & 7 & \\
\hline \multirow{2}{*}{$\begin{array}{l}\text { Operative period } \\
\text { total electrolyte } \\
\text { solution infused (ml) } \\
\text { total Na+ infused } \\
(\mathrm{mEq}) \\
\Delta \mathrm{PV}(\mathrm{ml})\end{array}$} & 2000 & 2000 & 2000 & 3000 & 2500 & 2000 & 4000 & 2500 \\
\hline & $\begin{array}{l}280 \\
120\end{array}$ & $\begin{array}{l}310 \\
320\end{array}$ & $\begin{array}{l}280 \\
400\end{array}$ & $\begin{array}{l}420 \\
590\end{array}$ & $\begin{array}{l}325 \\
300\end{array}$ & $\begin{array}{l}280 \\
380\end{array}$ & $\begin{array}{l}560 \\
880\end{array}$ & $\begin{array}{l}350 \\
430\end{array}$ \\
\hline \multirow{2}{*}{$\begin{array}{l}\text { Total operative day } \\
\text { total electrolyte } \\
\text { solution infused }(\mathrm{ml}) \\
\text { total } \mathrm{Na}^{+} \text {infused } \\
\quad(\mathrm{mEq}) \\
\Delta \mathrm{PV}(\mathrm{ml})\end{array}$} & 2570 & 4700 & 3100 & 3290 & 3500 & 3000 & 4000 & 3500 \\
\hline & $\begin{array}{l}360 \\
510\end{array}$ & $\begin{array}{l}695 \\
800\end{array}$ & $\begin{array}{l}435 \\
680\end{array}$ & $\begin{array}{r}460 \\
1110\end{array}$ & $\begin{array}{l}470 \\
410\end{array}$ & $\begin{array}{l}420 \\
700\end{array}$ & $\begin{array}{r}560 \\
1640\end{array}$ & $\begin{array}{l}485 \\
840\end{array}$ \\
\hline
\end{tabular}

Total blood volume (Bv), plasma volume (Pv), red cell volume (RCv), large vessel microhaematocrit, serum proteins, and serum electrolytes were determined immediately preoperatively, postoperatively on arrival in the recovery room, and 24 hours from the beginning of operation. Chromium ${ }^{51}$ or RUSA was used to measure BV, and control studies showed they give comparable results. Six determinations in one subject with RISA yielded a coefficient of variation for BV of \pm 6.2 per cent, and for $\mathrm{RCV}$ of \pm 3.8 per cent. Three determinations in each of three subjects with Chromium ${ }^{61}$ resulted in a cofficient of variation for BV of \pm 3.0 per cent, and for RCV \pm 2.1 per cent. All samples were taken in duplicate and counted in the Volemetron. Because $\mathrm{RCV}$ is more stable than BV, reproducibility of RCV is considered to be a good test of the method. In our patients, fractional changes in $\mathrm{PV}$ were found to correlate well with fractional changes in large vessel microhaematocrit $(r=0.97)$. 


\section{Results}

Table IV summarizes the results in the operative period. The control group sustained a mean blood loss of $760 \mathrm{ml}, 21$ per cent of preoperative $\mathbf{B v}\left(\mathbf{B v}_{0}\right)$, and received only maintenance amounts of 5 per cent $\mathrm{D} / \mathrm{W}$. No expansion of $\mathrm{PV}$ was observed at the end of operation. The treatment group sustained a mean blood loss of $920 \mathrm{ml}, 24$ per cent of $\mathrm{Bv}_{0}$, and received an average of $2500 \mathrm{ml}$ of electrolyte solution, 2.7 times the blood loss. Mean $\Delta \mathrm{PV}$ was $430 \mathrm{ml}$, replacing 46 per cent of the blood loss. Of the infused electrolyte solution, 16 per cent remained intravascular. Patient no. 1 had only 6 per cent intravascular retention, but this case involved more dissection and tissue handling, therefore presumably more tissue sequestration of fluid; and the patient had evidence of preoperative dehydration (serum $\mathrm{Na}^{+}, 154$ ). About 20 per cent intravascular retention was most commonly observed. The difference in $\Delta \mathrm{PV}$ between the two groups is significant $(p<0.01)$.

Because patients in the control group had either blood or electrolyte solution administered postoperatively, no comparison can be made between the two groups at 24 hours. At that time the treatment group had received an average total of $3500 \mathrm{ml}$ of electrolyte solution. $\Delta \mathrm{PV}$ was $840 \mathrm{ml}$ (Table III), replacing 84 per cent of the blood loss. Of this, 28 per cent $(1000 \mathrm{ml})$ was administered postoperatively. Of the electrolyte solution administered, there was 24 per cent intravascular retention at 24 hours.

No statistical variation in serum electrolytes was observed in either group postoperatively. Red cells and serum albumin were diluted in the treatment group (Figures 1 and 2) in proportion to the expansion of PV. The lowest haematocrits observed were near 30 , which was the point at which we had decided whole blood replacement would begin. ${ }^{3}$

Table $\mathrm{V}$ is condensed from the intake and output records for the operative and first postoperative days. During the operative day the treatment group received twice as much fluid as the control group (5940 ml vs $2930 \mathrm{ml}$ and six times as much sodium ( $485 \mathrm{mEq}$ vs $85 \mathrm{mEq}$ ). It excreted more than twice as much urine $(1360 \mathrm{ml}$ vs $560 \mathrm{ml}, \mathrm{p}<0.05)$. There was no significant difference in urine excretion in the 24-48 hour period despite a continued excess of fluid and sodium intake in the treatment group. When all external losses were measured, and assuming equal insensible losses in the two groups ( $1000 \mathrm{ml}$ per day), the net fluid balance of the control group at 48 hours was $-730 \mathrm{ml}$, and that of the treatment group was $+2450 \mathrm{ml}$. Since serum electrolyte concentrations in the treatment group were unchanged, this represents isionic isotonic ECF expansion. Of this ECF expansion $840 \mathrm{ml}$ was intravascular $(\Delta \mathrm{Pv})$; therefore the interstitial fluid excess amounted to about $1.5 \mathrm{~L}$.

\section{Discussion}

The normal plasma volume to interstitial fluid ratio is $1: 4$. Moore et al. ${ }^{4}$ have shown that in normal awake volunteers subjected to blood loss, administered saline was preferentially retained in the intravascular compartment. Our results suggest that electrolyte solution administered during operation distributes in 


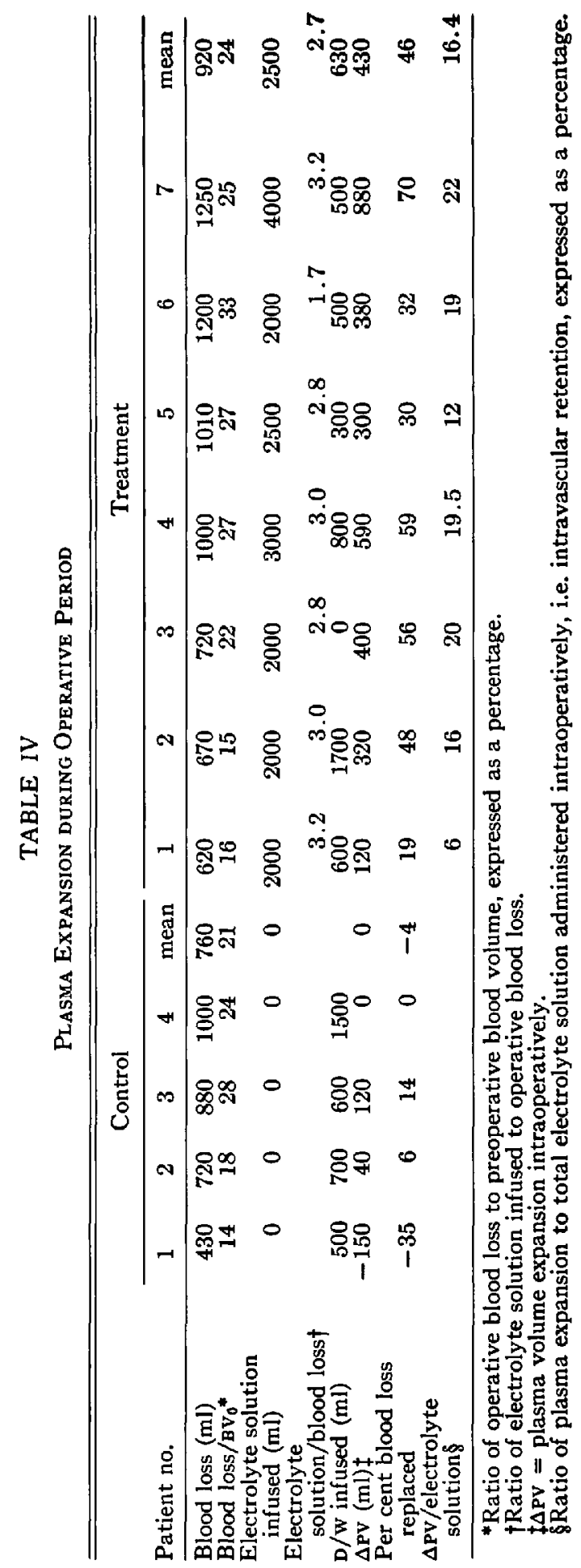




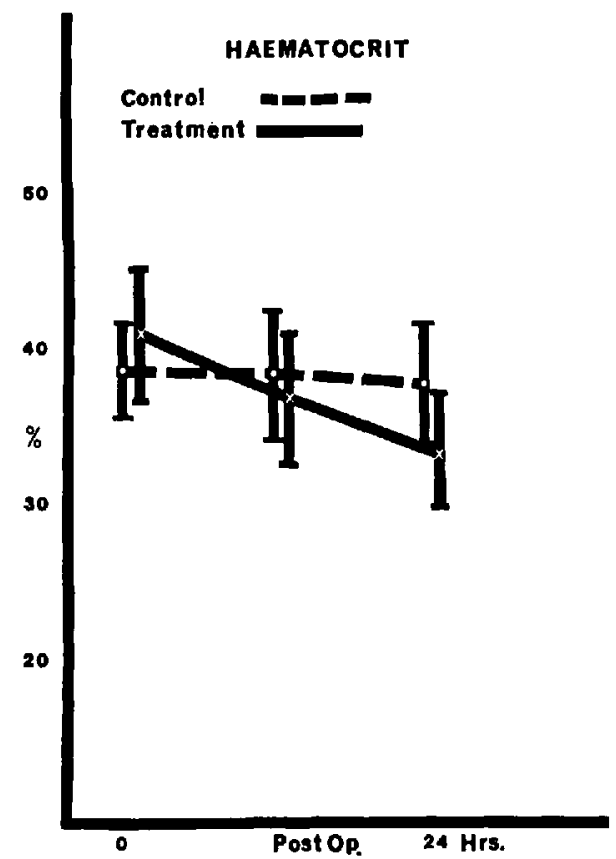

Figure 1. The vertical bars equal \pm 1 s.d.

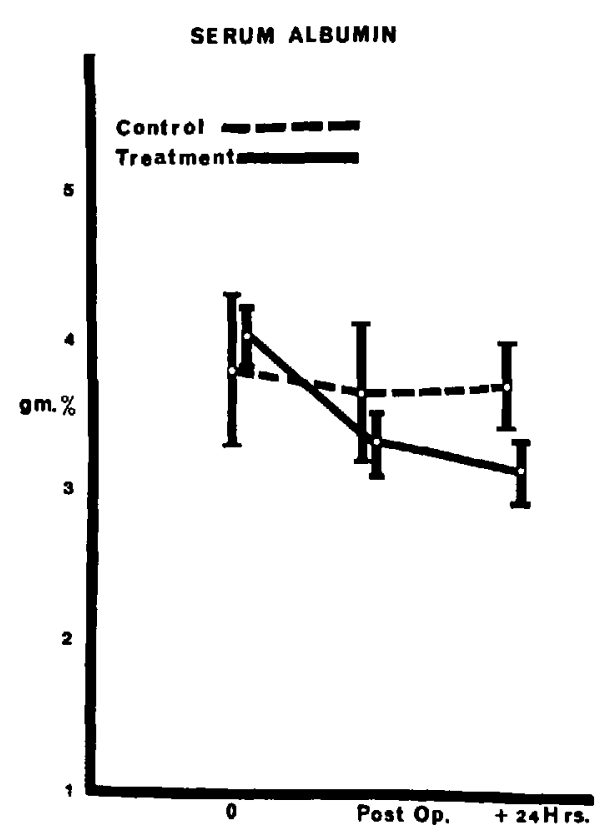

Figure 2. The vertical bars equal \pm 1 s.d.

TABLE $V$

INTAKE AND OUTPUT

\begin{tabular}{|c|c|c|c|c|c|c|c|}
\hline & \multicolumn{3}{|c|}{$0-24$ hours } & \multicolumn{3}{|c|}{$24-48$ hours } & \multirow{3}{*}{$\begin{array}{c}\text { Net } \\
\text { balance } \\
(48 \text { hrs }) \dagger\end{array}$} \\
\hline & \multicolumn{2}{|c|}{ intake } & \multirow[b]{2}{*}{$\underset{(\mathrm{ml})}{\operatorname{urine}^{*}}$} & \multicolumn{2}{|c|}{ intake } & \multirow[b]{2}{*}{$\begin{array}{c}\text { urine } \\
(\mathrm{ml})\end{array}$} & \\
\hline & $\underset{(\mathrm{mEq})}{\mathrm{Na}}$ & $\begin{array}{l}\text { fluid } \\
\text { (ml) }\end{array}$ & & $\underset{(\mathrm{mEq})}{\mathrm{Na}}$ & $\begin{array}{r}\text { fluid } \\
(\mathrm{ml})\end{array}$ & & \\
\hline \multicolumn{8}{|c|}{$\begin{array}{l}\text { Patient number } \\
\text { (control group) }\end{array}$} \\
\hline $\begin{array}{c}1 \\
2 \\
3 \\
4 \\
\text { Mean }\end{array}$ & $\begin{array}{r}154 \\
180 \\
0 \\
0 \\
85\end{array}$ & $\begin{array}{l}2850 \\
3750 \\
1885 \\
3240 \\
2930\end{array}$ & $\begin{array}{l}750 \\
750 \\
375 \\
380 \\
560\end{array}$ & $\begin{array}{l}0 \\
0 \\
0 \\
0 \\
0\end{array}$ & $\begin{array}{l}2320 \\
1820 \\
2695 \\
2620 \\
2360\end{array}$ & $\begin{array}{l}2830 \\
3300 \\
2700 \\
3460 \\
3072\end{array}$ & $\begin{array}{r}-120 \\
-1370 \\
-500 \\
-930 \\
-730\end{array}$ \\
\hline \multicolumn{8}{|c|}{$\begin{array}{l}\text { Patient number } \\
\text { (treatment group) }\end{array}$} \\
\hline $\begin{array}{c}1 \\
2 \\
3 \\
4 \\
5 \\
6 \\
7 \\
\text { Mean }\end{array}$ & $\begin{array}{l}360 \\
695 \\
435 \\
460 \\
470 \\
420 \\
560 \\
485\end{array}$ & $\begin{array}{l}6600 \\
8850 \\
4000 \\
5360 \\
6420 \\
4350 \\
6000 \\
5940\end{array}$ & $\begin{array}{r}1960 \\
1710 \\
800 \\
855 \\
2250 \\
1350 \\
625 \\
1360\end{array}$ & $\begin{array}{r}80 \\
0 \\
0 \\
154 \\
0 \\
230 \\
0 \\
66\end{array}$ & $\begin{array}{l}3500 \\
2850 \\
3125 \\
3690 \\
1970 \\
4500 \\
\mathbf{4 5 5 0} \\
\mathbf{3 4 5 5}\end{array}$ & $\begin{array}{l}4820 \\
2430 \\
1750 \\
1350 \\
2775 \\
2600 \\
2450 \\
2596\end{array}$ & $\begin{array}{r}+920 \\
+4390 \\
+2065 \\
+3725 \\
-185 \\
+1830 \\
+4315 \\
+2450\end{array}$ \\
\hline
\end{tabular}

"Urine output of the treatment group for the operative day $(1360 \mathrm{ml})$ is significantly greater than that of the control group $(560 \mathrm{ml}): p<0.05$. There is no significant difference in output between the groups on the first postoperative day.

†Indicates insensible and total measured losses. Insensible loss is assumed to be $1000 \mathrm{ml} / \mathrm{day}$. 
approximately the ratio of plasma volume to interstitial fluid, that is, $1: 4$. However, intraoperative fluid shifts are complex, and the net effects of blood loss, anaesthesia, and surgical trauma are difficult to predict precisely. Fluid requirements include replacement of preoperative ECF deficits, increased insensible loss, urine excretion, and ECF sequestered in traumatized tissue. Shires ${ }^{5}$ has measured a "functional ECF deficit" during surgery, which may represent a combination of the above effects. It appears that these encroachments on ECF volume prejudice the distribution of administered electrolyte solution, as evidenced by the varying proportion of intravascular retention we have observed. Those patients with preoperative fluid deficit, long traumatic surgery, or large intraoperative urine output had poorest intravascular retention.

Of the total electrolyte solution administered during the operative day, 72 per cent was infused during operation and 28 per cent over the remainder of the 24 hours. At the same time, plasma expansion was about equal in the operative and postoperative periods ( 430 vs $410 \mathrm{ml}$ ), with replacement of blood loss 84 per cent complete by 24 hours. While there may be better intravascular retention postoperatively, there is probably also enhancement of interstitial to intravascular shifts. Utilizing electrolyte solution in this manner, we have not observed plasma expansion to be a transient phenomenon.

A considerable expansion of total ECF persisted up to 48 hours postoperatively. The consequences of this on cardiopulmonary function are not entirely clear at present. There is some suggestion from studies of trauma victims that excessive administration of electrolyte solution may contribute to development of the "wet lung" syndrome in severely injured, shocked patients. ${ }^{\circ}$ Because the effects on pulmonary function of ECF expansion combined with anaesthesia, surgery, and blood loss have not been clearly elucidated, we exercise caution in administering electrolyte solutions during surgery to patients with cardiopulmonary disease.

\section{SUMMARY}

We have found plasma expansion with a balanced electrolyte solution to be a useful method of avoiding intraoperative whole blood replacement in selected cases with moderate operative blood loss ( $<25$ per cent). In the cases under review the amount infused during the operative period equalled three times the blood loss, and at the end of the operative day four times the blood loss had been given. We found that 20 per cent of the solution administered was intravascular at the end of operation and 25 per cent by the end of the operative day. Intravascular retention is, however, biased by preoperative deficits, tissue sequestration, and insensible losses. Blood volume expansion was 84 per cent complete by 24 hours, and a considerable expansion of interstitial fluid volume was found to persist up to 48 hours. Because of this we have limited this technique to reasonably healthy surgical patients without cardiopulmonary disease.

\section{RÉSUMÉ}

Dans le but d'éviter le remplacement per opératoire de sang total dans des cas choisis où la perte de sang est demeurée inférieure à 25 pour cent, nous 
sommes d'avis que l'augmentation du volume plasmatique par une solution équilibrée en électrolytes est une méthode utile. La quantité donnée durant l'opération est égale à trois fois celle de la perte sanguine et, à la fin du premier jour, quatre fois la quantité des pertes sanguines a été donnée.

A la fin de l'opération, 20 pour cent de la quantité de la solution donnée était demeurée dans les vaisseaux et, à la fin de la première journée, 25 pour cent. Cette rétention introvasculaire peut varier, toutefois, selon le déficit pré-opératoire, la rétention dans les tissus, les pertes insensibles. Dans les 24 heures, la masse sanguine circulante était complète à 84 pour cent et, après 48 heures, il persistait une augmentation considérable du volume du liquide interstitiel. A cause de ces données, nous avons réservé l'emploi de cette technique aux opérés assez bien portants sans pathologie cardio-pulmonaire.

\section{ACKNOWLEDGMENTS}

This study was supported by a grant from Abbott Laboratories Ltd. The technical assistance of Miss Heather McRae and Miss Judy Dunford is gratefully acknowledged.

\section{REFERENCES}

1. Rigor, B.; Bosomworth, P.; \& Rush, B. F. JR. Replacement of Operative Blood Loss of More than 1 Liter with Hartmann's Solution. J.A.M.A. 203: 399 (1968).

2. Boba, Antonio. Responses to Hemorrhage Replaced by Lactated Ringer's Solution. Acta. Anesth. Scandinav. Suppl. 31, April (1968).

3. Rush, B. F. Jr. \& Stewart, R. A. More Liberal Use of a Plasma Expander. New England. J. Med. 280: 1202 (1969).

4. Moone, F. D. et al. Hemorrhage in Normal Man: Distribution and Dispersal of Saline Infusions Following Acute Blood Loss. Ann. Surg. 163: 485 (1966).

5. SHmes, T. et al. Acute Changes in Extra-cellular Fluids Associated with Major Surgical Procedures. Ann. Surg. 154: (1961).

6. Mrls, M. \& Mrtchell. Pulmonary Effects of Non-Thoracic Trauma: The Clinical Syndrome. J. Trauma. 8: 651 (1968). 